2. Шлапак І.П., Галушко О.А. Інтенсивна терапія діабетичного кетоацидозу у хворих на ішемічний інсульт. Ocтрые и неотложные состояния в практике врача. 2015. $812 \mathrm{c.}$

3. Sharma A.N., Wigham J., Veldhuis J.D. Corticotropic axis drive of overnight cortisol secretion is suppressed in adolescents and young adults with type 1 diabetes mellitus. Pediatr Diabetes. 2014. № 15(6). C. 444-452.

4. Revsin Y., D. van Wijk, Saravia F.E. Adrenal hypersensitivity precedes chronic hypercorticism in streptozotocin-induced diabetes mice. Endocrinology. 2008; №149(7). C. 3531-3539.

5. Жураківська О.Я., Міськів В.А., Ткачук Ю.Л., Дутчак У.М., Гречин А.Б., Клипич Я.І. Морфофункціональні зміни гіпоталамо-гіпофізарно-надниркової системи при експериментальному цукровому діабеті. Conference Proceedings. Innovative technology in medicine: experience of Poland and Ukraine. (Lublin, 28-29 April 2017). Lublin, 2017. C. 117-121.

DOI https://doi.org/10.30525/978-9934-26-113-8-26

\title{
МОРФОЛОГІЧНІ ЗМІНИ ГІПОФІЗАРНО-ЯЕЧКОВОЇ ВІСІ ПРИ СТРЕПТОЗОТОЦИНОВОМУ ЦУКРОВОМУ ДІАБЕТІ
}

\author{
Себро О. Г. \\ аспірант кафедри клінічної анатомії та оперативної хірургії \\ Івано-Франківський національний медичний університет
}

Жураківська О. Я.

доктор медичних наук, професор, професор кафедри анатомії людини Івано-Франківський національний медичний університет

\section{Кулинич Г. Б.}

кандидат медичних наук, доиент, доиент кафедри гістології, ичитології та ембріології Івано-Франківський національний медичний університет м. Івано-Франківськ, Украӥна

Цукровий діабет (ЦД) $є$ однією 3 найбільш актуальних проблем клінічної медицини, що зумовлено широкою поширеністю, клінічним поліморфізмом, тяжкістю ускладнень. 3 кожним роком його частота 
неухильно зростає і сьогодні у світі на ЦД хворіють більше 110 млн. чоловік [3, 4]. В Свропі питома вага таких хворих становить близько 4\% [4]. В Україні офіційно заресстровано більше мільйона хворих на цукровий діабет (2,4\% від всього населення), проте реально кількість людей з недіагностованою патологією перевищує цю цифру у 3-4 рази [4]. Поза увагою дослідників залишились морфофункціональні зміни гіпофізарно-гонадної системи при цукровому діабеті, хоча за оціночними даними, в Україні спостерігається біля 1 млн. безплідних подружніх пар [1]. За даними наукової літератури гіперглікемія призводить до окислювального стресу та посилення процесів утворення активних форм кисню [6], які в свою чергу роблять значний внесок у розвиток чоловічого безпліддя. Тому метою нашого дослідження було встановлення морфо-функціональних змін в гонадотропних ендокриноцитах аденогіпофіза та паренхімі яєчок при стрептозотоциновому цукровому діабеті (СЦД).

Матеріалом для дослідження служили шматочки аденогіпофізу, яєчок 10-ти білих лабораторних щурів-самців 12-міс віку, які порівну розподілялись на дві групи: контрольну та експериментальну. Щурам експериментальної групи моделювали СЦД шляхом внутрішньоочеревинного введення стрептозотоцину (6 мг на 100 г маси тіла) розчиненого в $0,1 \mathrm{M}$ цитратному буфері $3 \mathrm{pH} 4,5$. Контрольній групі в еквівалентній дозі вводили $0,1 \mathrm{M}$ цитратний буфер $3 \mathrm{pH} 4,5$. Матеріал забирали на 28 добу після експерименту. Використали гістологічний, електронномікроскопічний, біохімічний, морфометричний та статистичний методи дослідження.

На 28-у добу експерименту рівень глюкози і глікованого гемоглобіну

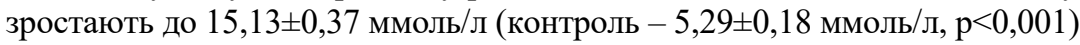
та $8,15 \pm 0,18 \%$ (контроль $-2,03 \pm 0,08 \%, \mathrm{p}<0,001$ ).

У щурів із СЦД кількість гонадотропів на площі $0,01 \mathrm{mм}^{2}$ достовірно не змінюється, порівняно 3 контрольними показниками, i становить $8,64 \pm 0,06$ (контроль - 10,5 $\pm 1,02$ ). У світлих і темних гонадотропних ендокриноцитах на ультраструктурному рівні відмічаються ознаки підвищення секреторної активності, що проявляються збільшенням протяжності цистерн, канальців та кількості пухирців комплексу Гольджі, цистерн і вакуолей гранулярної ендоплазматичної сітки рибосом на їх поверхні, збільшенням об'ємної щільності секреторних гранул (СГ) у світлих гонадотропах в 1,5 раза, тоді як темних вона вірогідно не змінюється. Зростання об'ємної щільності СГта наявність різних типів гонадотропів (гіпер-, помірно- і дегранульованих), а також, поява клітин кастрації вказують на посилений синтез та виведення секрету із клітин. 
У цей термін у паренхімі яєчок відмічається потовщення базальної мембрани звивистих сім'яних трубочок та зміщення шарів сперматогенного епітелію в бік їх просвіту. Морфометричне дослідження яєчок при СЦД показало достовірне зменшення площі поперечного перерізу звивистих сім'яних трубочок за рахунок зменшення висоти сперматогенного епітелію. В просвіті сім'яних трубочок визначалось поступове зменшення кількості шарів та клітин сперматогенного епітелію. В частині сперматогоній виявляється деструкція крист мітохондрій, збільшується кількість дрібних вакуолей. У сперматоцитах та сперматидах на стадії прелептотени цитоплазма має низьку щільність, в деяких клітинах відмічаються частково зруйновані мітохондрії. Найбільш виражених змін зазнають сустентоцити, в цитоплазмі яких 3'являється велика кількість різних розмірів вакуолей, ліпідних крапель $\mathrm{i}$ лізосом. Поряд 3 цим, контакти між підтримуючими клітинами не порушуються. У клітинах Лейдіга відмічаються подібні ультраструктурні зміни, а їх особливою ознакою є зменшення кількості СГ. Також спостерігається велика варіація в процесі сперматогенезу, а саме, передчасне відшарування сперматид, далі розвивалось відшарування сперматоцитів, що в кінцевому рахунку призводило до повної атрофії гермінативного епітелію.

Морфофункціональні зміни аденогіпофізу і яєчок експериментальних тварин при ЦД у більшій мірі є взаємозв'язаними [2]. Дистрофічнодеструктивні зміни яєчок, включаючи гормонопродукуючі структури (клітини Лейдіга) проявляються порушенням не тільки гермінативної, а i гормональної функції даного органа. Це підтверджується і даними інших дослідників $[1,2,5]$, які відмічали зниження в крові щурів рівня тестостерону при СЦД. У таких умовах за механізмом зворотного зв'язку, відбувається активація гормональної активності гонадотропів аденогіпофіза, що проявляється описаними нами їх морфологічними змінами. Поряд 3 цим функціональне перевантаження гонадотропів аденогіпофіза в кінцевому результаті приводить до їх деструктивних змін.

Отже, СЦД призводить до порушення функціонування гіпофізарнояєчкової вісі. СЦД викликає гіпоплазію і гіпотрофію сперматогенного епітелію та дистрофічні зміни в клітинах Лейдіга. За таких умов за механізмом зворотного зв'язку, відбувається активація гормональної активності гонадотропів аденогіпофіза, що проявляється появою в ньому клітин кастрації та зростанням об'ємної щільності СГ у світлих гонадотропах. 


\section{Література:}

1. Baccetti B. Insulin-dependent diabetes in men is associated with hypothalamo-pituitary derangement and with impairment in semen quality / B. Baccetti, A. La Marca, P. Piomboni // Hum. Reprod. 2002. Vol. 17, № 10. P. 2673-2677.

2. Chabrolle C. Effects of high levels of glucose on the steroidogenesis and the expression of adiponectin receptors in rat ovarian cells / C. Chabrolle, E. Jeanpierre, L. Tosca // Reprod Biol Endocrinol. 2008. Vol. 19. P. 6-11.

3. Chudhary D, Cleveland DA, Agdere L, Graetz R, Etienne D. [Does the Use of Diabetes Electronic Medical Record Template Lead to Improvement of Screening for Complications of Tipe 1 Diabetes Mellitus in the Pediatric Population]. Pediatrics. 2018; 141(1): 122-8.

4. Francesco Cosentino, Peter J. Grant, Victor Aboyans. 2019 ESC guidelines on diabetes, pre-diabetes, and cardiovascular diseases developed in collaboration with the EASD. European Heart Journal. 2019. P. 1-69.

5. Pituitary-testicular axis function, biological to immunological ratio and charge isoform distribution of pituitary LH in male rats with experimental diabetes / A. Olivares, J.P. Méndez, M. Cárdenas [et al.] // Gen. Comp. Endocrinol. 2009 - Vol. 161, № 3. - P. 304-312.

6. Ullah A, Khan A, Khan I. [Diabetes mellitus and oxidative stress-A concise review.] Saudi Pharmaceutical Journal. 2016; 24:547-53. 